Yayın Geliş Tarihi: 16.07.2020

Yayına Kabul Tarihi: 29.08.2021

Online Yayın Tarihi: 30.09.2021

http://dx.doi.org/10.16953/deusosbil.770572
Dokuz Eylül Üniversitesi

Sosyal Bilimler Enstitüsü Dergisi

Cilt: 23, Say1: 3, Y11: 2021, Sayfa: 1001-1023

ISSN: 1302-3284 E-ISSN: 1308-0911

Araştırma Makalesi

\title{
GAZETE KÖŞE YAZISI SÖYLEMI KAPSAMINDA YENİ BARO DÜZENLEMESİ: SÖYLEM-TARİHSEL YAKLAŞIM ÇERÇEVESINDE BİR ÇÖZÜMLEME
}

\author{
Plnar DANIŞ*
}

\section{$\ddot{O} z$}

Söylemin eleştirel olarak incelenmesine yönelik yaklaşımlarından olan SöylemTarihsel Yaklaşım, 'olumlu biz', 'olumsuz onlar' temsilinin gerçekleştirilmesine aracılık eden söylemsel stratejileri içermektedir. Bu stratejilerden biri olan ve çalışmamızın inceleme kapsamını oluşturan yükleme, 'biz' ve 'onlar' arasındaki grup içi olumlu ve grup dışı olumsuz etiketlemeyi amaçlayan yüklemeleri ortaya koymaktadır. Bu çalışmada yükleme, toplumsal aktörlerin, olayların ve olguların gazetenin ve yazarın ideolojik eğilimi doğrultusunda betimlendiği ve okuyucuların, bu çerçevede ikna edilmesinin amaçlandı̆̆ bir medya metin türü olan gazete köşe yazlları çerçevesinde incelenmektedir. Bu çalışmanın amacl, karşıt ideolojik yönelime sahip gazetelerde yükleme stratejilerinin belirlenmesi; böylece aynı gerçekliğin farklı ideolojik yönelime sahip gazetelerde nasıl betimlendiğinin ve söylemin karşıt ideolojiler tarafindan nasıl biçimlendirildiğinin ortaya koyulmasıdır. Veritabanını oluşturan köşe yazılarının çözümlenmesi sonucunda farklı ideolojik yönelime sahip olan Cumhuriyet ve Sabah ulusal günlük gazetelerinde yeni baro düzenlemesinin farkl biçimde temsil edildiği ve bir gazetede olumlu olarak betimlenen toplumsal aktörlerin ve olguların, diğer gazetede olumsuz olarak betimlendiği sonucuna ulaşılmıştır. Bu açıdan çalışmanın bulguları, medya söylemi ve politik ideoloji arasında güçlü bir ilişki olduğunu ortaya koymaktadır.

Anahtar Kelimeler: Söylem, Eleştirel Söylem Çözümlemesi, Söylem-Tarihsel Yaklaşım, Medya Söylemi, Gazete Köşe Yazısı Söylemi

Bu makale için önerilen kaynak gösterimi (APA 6. Sürüm):

Danış, P. (2021). Gazete köşe yazısı söylemi kapsamında yeni baro düzenlemesi: Söylemtarihsel yaklaşım çerçevesinde bir çözümleme. Dokuz Eylül Üniversitesi Sosyal Bilimler Enstitüsü Dergisi, 23 (3), 1001-1023.

* Doktora Öğrencisi, Dokuz Eylül Üniversitesi, Sosyal Bilimler Enstitüsü, Genel Dilbilim Anabilim Dal1, ORCID: 0000-0002-2450-8154, danis.pinar@ogr.deu.edu.tr. 


\title{
REGULATION OF THE NEW BAR ASSOCIATION IN OP-ED ARTICLES: AN ANALYSIS WITHIN THE FRAMEWORK OF DISCOURSE-HISTORICAL APPROACH
}

\begin{abstract}
Discourse-Historical Approach, which is one of the approaches to critically analyze discourse, includes discursive strategies that mediate the representation of 'positive us', 'negative them'. Predication, which is one of these strategies and constitutes scope of our study, reveals predications between "us" and "them" showing positive predications about in-group and negative predications about out-group. In this study, these predications is analyzed in the framework of op-ed articles, which is the media discourse genre in which social actors, events and facts are described in line with the ideological tendency of the newspaper and intended to persuade the readers within the framework of the ideology of the newspaper. The aim of this study is to determine the predication strategies in newspapers with opposed ideological orientation, and to reveal how the same reality is described in newspapers with different ideological orientations and how the discourse is shaped by opposing ideologies. As a result of the analysis of the op-ed articles that constitutes the database, it has been concluded that the new baro regulation was represented differently in the national daily newspapers Cumhuriyet and Sabah, which have different ideological orientations, and the social actors and phenomena that are described positively in one newspaper are described negatively in the other newspaper. This study aims to contribute to the discipline in terms of making the ideological dimension of discourse visible and providing a linguistic perspective on the Critical Discourse Analysis approach used in different disciplines. In this respect, the findings of the study reveal that there is a strong relationship between media discourse and political ideology.
\end{abstract}

Keywords: Discourse, Critical Discourse Analysis, Discourse-Historical Approach, Media Discourse, Discourse of Op-ed Articles

\section{GíRiș}

Çağdaş dünyanın ayırt edici özelliği olan mücadeleler ve karşıtlıklar, karmaşık ve ayrışık görünümlere yol açmaktadır (Wodak, 2001, s. 63). Uzamın ve zamanın parçalara ayrıldığı hızlı dönüşen bir dünyada toplumların bu karmaşık görünümü (Harvey, 1996), belirli bir toplumu oluşturan farklı gruplar arasındaki çoklu etkiler ve farklı toplumlar arasındaki ilişkiler ${ }_{2}$ yalnızca çok etmenli bir model ile anlaşılabilmektedir. Yalnızca alanlar arası bir araştırma söz konusu karmaşıklıkları görünür kılmakta, bu tür bir incelemede eleştirel söylem çözümlemesi (ESÇ) gerekli olan çoklu yaklaşımın yalnızca tek bir bileşenini oluşturmaktadır (Wodak, 2001, s. 63-64). Söylemin ardında bulunan ideolojinin dilbilim temelli bir yaklaşımla ortaya çıkarılması olan ESÇ’nin inceleme alanları Kress (1990) tarafından "1rkçılığın ve cinsiyetçiliğin söylem yoluyla yeniden üretimi; gücün meşrulaştırılması; rızanın üretimi; politikanın, eğitimin ve medyanın yeniden üretimdeki rolü; gruplar arasındaki baskın ilişkinin söylemsel yeniden üretimi ve uluslararası iletişim ve bildirişimdeki dengesizliklerdir." biçiminde özetlenmektedir. Dilsel birimleri tek tek 
incelemek değil söylemi ve karmaşık toplumsal olguları incelemek olan ESÇ; dolayısıyla çok alanlı ve çok yöntemli bir yaklaşım gerektirmektedir (Wodak ve Meyer, 2009, s. 2). İdeolojilerin açıklaştırılmasında, iletilmesinde, normalleştirilmesinde ve meşrulaştırılmasında etkili olan söylem (van Dijk, 1990, s. 177), çağdaş toplumlarda toplumsal gücün bir aracıdır ve bu güç aracının işletilme biçiminin anlaşılması sıklıkla güçtür (Blommaert, 2005, s. 25). Bu kapsamda odaklanılması gereken olgu yalnızca söylemsel kılgılar değil aynı zamanda çeşitli maddesel ve göstergesel kılgılardır ve ESÇ kapsamında bir inceleme çok kuramlı, yöntemli, eleştirel ve özyansitımlıdır (Wodak, 2001, s. 64).

Söyleme eleştirel yaklaşımlar kapsamında geliştirilen bir yaklaşım olan Söylem-Tarihsel Yaklaşım (STY) karmaşık ilişkilerin çözümlenmesi için tarihsel kaynaklar ve söylemsel olayların toplumsal ve politik olaylarla iç içe geçtiği toplumsal ve politik alanların artalanı hakkındaki bilgiyi üçgenlemekte, bütünleştirmekte ve örtük güç ilişkilerini incelemeye yönelik bir araç sunmaktadır (Wodak, 2009, s. 38). Diğer bir deyişle, STY, söylemi incelerken dilsel boyutun yanı sıra söyleme etki eden tarihsel, toplumsal, politik ve ruhsal boyutları da ele almaktadır (Wodak ve Meyer, 2001, s. 65). Hakkında konuşulan ve yazılan "konular", kullanılan "söylemsel stratejiler" ve konuları ve stratejileri gerçekleştirmek amacıyla kullanılan "dilsel araçlar" olarak üç boyutlu bir yapıya sahip olan STY'de söylemsel stratejiler gönderim / adlaştırma (referential / nomination); yükleme (predication); savlama (argumentation); bakışaçılaştırma (perspectivation), çerçeveleme (framing), söylem temsili (discourse representation); yoğunlaştırma (intensification) ve hafifletme (mitigation) olarak söylemsel stratejilere sahiptir. Bu stratejilerden yükleme, toplumsal aktörleri olumlu ya da olumsuz, küçümseyici ya da takdir edici biçimde etiketlemedir (Wodak, 2009, s. 73).

Bir kurum olarak medya, toplumsal yeniden üretim sürecinde ideolojik ve politik işlevler yerine getirmektedir. İdeolojik açıdan medya, eyleme geçtiği toplumun ideolojik yapısını etkilemekte ve biçimlendirmektedir. Politik olarak ise, dünyayı diğer bireyler, diğer bir deyişle medya ürünlerinin tüketicileri için anlamlandırmayı olanaklı kılmaktadır. Medya, bu işlevi yerine getirirken, okuyucuların ideolojik konumlarına olan bağlılıklarını değiştirmeye ya da onların ideolojik bağl1lıklarını daha sıkı bir biçimde pekiştirmeye eğilimli duruma gelmektedir (Oktar, 2001, s. 320). Bir medya söylemi türü olarak gazete köşe yazıları söylemi hedef kitleyi etkilemeyi ve ikna etmeyi amaçlamaktadır. Köşe yazarları dünyaya ilişkin bilgi verirken ve olayları yorumlarken kendilerinin ve üyesi oldukları gazetenin ideolojisi doğrultusunda açık ya da örtük belirli dilsel seçimler yaparak tutum ve yargıları ortaya koymaktadır (Ercan ve Dizdarcı, 2016, s. 98).

$\mathrm{Bu}$ çalışmada gazete köşe yazısı bağlamında medya söylemi, Wodak'ın Söylem-Tarihsel yaklaşımı kapsamında yer alan stratejilerden olan yükleme çerçevesinde incelenmektedir. Çalışmanın veritabanını, Cumhuriyet ve Sabah 
gazetelerinde yayımlanan ve Türkiye'de iktidar tarafından gündeme getirilen yeni baro düzenlemesini konu alan köşe yazıları oluşturmaktadır. Çalışmanın veritabanını oluşturan karşıt ideolojiye sahip gazetelerde aynı konuya ilişkin olarak yazılan köşe yazılarının çözümlenmesiyle, köşe yazarları tarafından yeni baro düzenlemesine ilişkin kullanılan yükleme stratejilerinin belirlenmesi ve bunun sonucunda aynı gerçekliğin farklı ideolojik görüşe sahip yazarlar tarafından nasıl ortaya koyulduğunun, söylemin farklı ve karşıt ideolojiler tarafindan nasıl biçimlendirildiğinin ve ideolojilerin yeniden üretiminde söylemin rolünün ortaya koyulması amaçlanmaktadır. $\mathrm{Bu}$ doğrultuda ilk olarak ESÇ'ye yönelik yaklaşımlardan biri olan STY'nin ve STY kapsamındaki stratejilerden biri olan yükleme stratejisinin ayrıntılı olarak ele alınması amacıyla bir sonraki başlıkta STY'ye yer verilmektedir.

\section{SÖYLEM-TARİHSEL YAKLAŞIM}

Yazılı ve sözlü dil kullanımı olan söylem, hem toplumsal bir kılgı biçimidir (Fairclough, 1992, s. 63) hem de, toplumsal kılgının belirli bir alanını belirli bir bakış açısıyla belirtme biçimidir (Wodak, 2001, s. 66). Çağdaş toplumlarda söylem, güç ilişkilerinin ve toplumsal kimliklerin oluşturulmasında ve yeniden üretilmesinde ayırt edici bir role sahip olmasıyla öne çıkmaktadır (Fairclough, 2010, s. 97). ESÇ’de söylem, toplumsal bir kılg1 olarak görülmektedir ve bunun nedeni dilsel seçimlerin, toplumsal kılgıların gerçekleştirilmesi için kaçınılmaz kullanımlar; dilin toplumdan ayrılamaması, toplumun bir parçası olması ve toplumun dilsel olmayan alanlarının koşulladığı toplumsal bir süreç olmasıdır (Fairclough, 2001, s. 19; Yağcioğlu, 2002, s. 5). Söylem hem toplumsal olarak kurucu bir özelliğe sahiptir hem de toplum tarafından koşullandırılmaktadır (Fairclough ve Wodak 1997'den aktaran Wodak, 2014, s. 303). ESÇ'de söylem ve toplum arasındaki ilişki şu biçimde aktarılmaktadır:

“ESÇ, söylemi bir 'toplumsal eylem' biçimi olarak görmektedir. Söylemi toplumsal bir eylem olarak tanimlamak, belirli bir söylemsel olay ve onu biçimlendiren durumlar, kurumlar ve toplumsal yapılar arasındaki eytişimsel ilişkiye gönderimde bulunmaktadır: söylemsel olay bu ögeler tarafindan biçimlendirilmekte ve aynı zamanda bu ögeleri oluşturmaktadır. Bu nedenle söylem toplumsal olarak koşullu olmakla beraber kurucudur- durumlarl, bilgi nesnelerini, toplumsal kimlikleri ve insanlar ve gruplar arasındaki ilişkileri oluşturmakta;- hem statükoyu sürdürme ve yeniden üretme hem de onu dönüştürme açısından kurucu özellik taşımaktadır" (Fairclough ve Wodak, 1997, s. 258).

Buna koşut olarak Fairclough (2010) ESÇ’nin yalnızca metinlerin çözümlenmesi değil, söylem ile toplumsal sürecin diğer unsurları arasındaki ilişkilerin sistematik biçimde ve alanlar arası çözümlenmesinin bir parçası olduğunu ifade etmektedir. ESÇ, söylemin, gücün ve denetimin ayrılmaz bir 
parçası olduğunu varsayar ve bu açıdan gücün, bireyler ve kurumlar tarafından ortaya koyulduğunu ileri sürmektedir (Bloor ve Bloor, 2007, s. 4). Bu açıdan ESÇ araştırmacıları, dili toplumsal ve bilişsel bir olgu olarak ele almakta ve söylemin toplumsal düzlemde temsilleri, kimlikleri ve ideolojileri kurucu/inşa edici, sürdürücü, değiştirici ve denetleyici etkisine işaret etmektedir (Ercan ve Danış, 2019, s. 548).

ESÇ, yalnızca dilsel birimlerin incelenmesinden çok disiplinler ötesi ve çok yöntemli bir yaklaşım gerektiren karmaşık toplumsal olguların incelenmesidir. ESÇ, iletişimsel olaylar olarak söylemi çözümlemeye yardımcı olan bir dizi yaklaşımı benimsemektedir. Çok yönlü bir inceleme alanı olarak ESÇ'de önemli bir yere sahip bir yaklaşım olan STY'de söylemsel eylemlerle özel eylem alanları (durumlar, kurumsal ve toplumsal yapılar) arasında eytişimsel bir ilişkinin bulunduğu kabul edilmektedir. Diğer bir deyişle, toplumsal bir kılgı olarak söylem, söylemsel ve söylemsel olmayan davranışlar üretmekte ve bunlar tarafından yeniden üretilmektedir (Wodak, 2014, s. 302). ESÇ'nin önde gelen yaklaşımlarından biri olan STY'de büyük-ölçekli bir konuya ilişkin olan söylem, farklı bakış açılarına sahip toplumsal aktörleri içeren doğruluk geçerliliği ve kuralcı geçerlilik gibi geçerlilik iddiaları hakkındaki savlamayla ilgilidir. STY kapsamında söylem, toplumsal eylemin belirli alanlarına yerleştirilen bir dizi bağlam bağımlı göstergesel k1lg1, toplumsal olarak kurucu olmasının yanı sira toplumsal olarak oluşturulan ve farklılaşan konumları ve sesleri bütünleştiren bir eylem biçimi olarak tanımlanmaktadır (Wodak, 2009, s. 39).

STY'nin her durumda soruna yönelik bir bakış açısı seçen esnek ve üretken bir ESÇ yaklaşımı olduğunu ifade eden Reisigl (2017) bu nedenle STY'yi, söylemin incelenmesine ilişkin en önemli eleştirel yaklaşımlardan biri olarak nitelendirmektedir. Eleştirel kuramın sosyofelsefik yönelimine bağlı olan STY, birbirine bağl1, ikisi biliş ve biri eylem boyutuyla ilgili en az üç özelliği kapsayan karmaşık bir toplumsal eleştiri kavramını izlemektedir. Buna göre ilk özellik söylem-içkin eleştirinin, söylem içsel yapılardaki tutarsılılkları, öz-çelişkileri, çatışkıları ve ikilemleri; ikinci özellik, toplumsal tanılama eleştirisi söylemsel kılgıların örtük ikna edici ya da 'manipülatif' karakterini ortaya çıkarmayı amaçlamasıdır. Burada, bağlamsal bilgilerden yararlanılmakta ve söylemsel olayları yorumlamak için çeşitli disiplinlerdeki toplumsal kuramların yanı sıra diğer kuramsal modellerden de yararlanılmaktadır. Üçüncü özellik ise, sözgelimi, cinsiyetçi dil kullanımına karşı yönergeler hazırlayarak ya da hastanelerde, okullarda, vb. bağlamlarda 'dil engellerini' indirgenmesiyle geleceğe ilişkin ileriye dönük eleştirinin, iletişimin geliştirilmesine katkıda bulunmanın amaçlanmasıdır (Wodak ve Meyer, 2001, s. 65; Reisigl ve Wodak, 2008, s. 88).

STY, araştırmacıların yanlılığını en aza indirgemek için yöntemsel bir yol olarak üçgenleme (triangulation) ilkesini benimsemektedir. Böylelikle STY'yi diğer yaklaşımlardan ayıran en önemli özelliklerden biri çözümlemenin artalan bilgisini içermesi kadar onun çeşitli deneysel veriler temelinde ve çok yöntemli biçimde incelemede bulunma çabasıdır. STY tarihsel, örgütsel ve politik konuları 
ve metinleri incelemede söylemsel olayların bağlı bulunduğu toplumsal ve politik alanların geçmiş bilgisine ve tarihsel kaynaklarına ilişkin geniş çaplı bilgiyi bütünleştirme çabası içine girmektedir. Bununla birlikte STY'de söylemin belirli metin türlerinin artsüremli değişime uğrama biçimleri ortaya koyularak söylemsel olayların tarihsel boyutları çözümlenmektedir (Wodak, 2001, s. 65). Wodak (2015) STY'de 'biz' ve 'onlar' ayrımının söylemsel oluşumuna ve temsiline ilişkin belirli bir söylemin ve ilgili metinlerin çözümlenmesi aşamasında birkaç stratejinin belirlendiğini ifade etmektedir. STY, çeşitli söylemsel özelliklere ve stratejilere yaklaşımda yol gösterici nitelikte beş soru sormaktadır:

- Kişiler, nesneler, olgular/olaylar, süreçler ve eylemler nasıl adlandırılmakta ve bunlara nasıl gönderimde bulunulmaktadır?

- Bu toplumsal aktörlere, nesnelere, olgulara, süreçlere yüklenen özellikler ve nitelikler nelerdir?

- Söz konusu söylemde ne tür savlar kullanılmaktadır?

- $\mathrm{Bu}$ adlandırmalar, nitelikler ve savlar hangi bakış açısından ifade edilmektedir?

- İlgili ifadeler açıkça ifade edilmekte midir? Bu ifadeler yoğunlaştırılmakta ya da hafifletilmekte midir?

Bu sorulara uygun olarak, STY'de 'olumlu biz', 'olumsuz onlar' sunuşunu içeren, kimliğin inşasının ve içlemenin/dışlamanın gerekçelendirilmesine ya da meşrulaştırılmasına dayanak sağlayan beş tür söylemsel strateji bulunmaktadır. $\mathrm{Bu}$ kapsamda 'strateji' sözcüğüyle belirli bir toplumsal, politik, ruhsal ya da dilsel bir amacı yerine getirmek için benimsenen söylemsel kılgıları içeren az çok kesin ya da kasitlı bir kılgılar tasarısına gönderimde bulunulmaktadır. Bu stratejiler, tablo 1'de gösterilmektedir (Wodak, 2009, s. 40):

Tablo 1: Söylemsel Stratejiler

\begin{tabular}{|c|c|c|}
\hline Strateji & Amaçlar & Araçlar \\
\hline Gönderim/adlaştırma & $\begin{array}{c}\text { Grup içinin ve grup dişının } \\
\text { inşası }\end{array}$ & $\begin{array}{l}\text {-Üyeliğin ulamlaştırılması } \\
\text {-Biyolojik, doğallaştırıcı ve kişisizleştirici } \\
\text { eğretilemeler ve ad aktarmaları } \\
\text {-Kapsamlayış }\end{array}$ \\
\hline Yükleme & $\begin{array}{l}\text { Toplumsal aktörleri olumlu ve } \\
\text { olumsuz, küçümseyici ya da } \\
\text { takdir edici biçimde etiketleme }\end{array}$ & $\begin{array}{l}\text {-Olumlu ya da olumsuz özelliklerin } \\
\text { kalıpyargısal, değerlendirici nitelemeleri } \\
\text {-Örtük ve açı yüklemler }\end{array}$ \\
\hline
\end{tabular}




\begin{tabular}{|c|c|c|}
\hline Savlama & $\begin{array}{l}\text { Olumlu-olumsuz } \\
\text { nitelendirmelerin } \\
\text { gerekçelendirilmesi }\end{array}$ & $\begin{array}{l}\text {-Politik içlemenin ya da dışlamanın, } \\
\text { ayrımcılığın ya da ayrıcalıklı yaklaşımın haklı } \\
\text { çıkarılmasında kullanılan konu alanları }\end{array}$ \\
\hline $\begin{array}{l}\text { Bakışaçılaştırma, } \\
\text { çerçeveleme, söylem } \\
\text { temsili }\end{array}$ & $\begin{array}{l}\text { Katılımı ifade etme, } \\
\text { konuşucunun bakış açısını } \\
\text { konumlandırma }\end{array}$ & $\begin{array}{l}\text {-(ayrımcı) Olayların ya da sözcelerin bildirimi, } \\
\text { açıklaması, öykülenmesi ya da aktarımı }\end{array}$ \\
\hline $\begin{array}{l}\text { Yoğunlaştırma, } \\
\text { hafifletme }\end{array}$ & $\begin{array}{l}\text { Önermenin bilgisel durumunu } \\
\text { niteleme }\end{array}$ & $\begin{array}{l}\text {-(ayrımcı) Sözcelerin edimsöz etkisinin } \\
\text { yoğunlaştırılması ya da hafifletilmesi }\end{array}$ \\
\hline
\end{tabular}

Kaynak: Wodak, 2001, s. 73.

Tablo 1'de görüldüğü gibi STY çeşitli amaçların yerine getirilmesi için söylemsel stratejileri ve bu stratejilerin yerine getirilmesini sağlayan dilsel araçları içermektedir. $\mathrm{Bu}$ stratejilerden biri olan ve çalışmamızın inceleme kapsamını oluşturan yükleme, toplumsal aktörler olarak bireylerin, grup üyelerinin ya da bir bütün olarak grupların dilsel olarak nitelendirilmesidir. Wodak ve Meyer (2009) yüklemeyi, olumlu ya da olumsuz özelliklerin basmakalıp ve değerlendirici nitelemeleri ya da örtük ya da açık yüklemeler olarak tanımlamaktadır (Reisigl ve Wodak, 2008, s. 95). Çalışmamızın çözümleme bileşenini oluşturan yükleme, şu türden araçlarla ortaya koyulmaktadır:

- sıfatlar, eşlemeler, ilgeç öbekleri, ilgi tümcecikleri, eylemlik tümceleri, ortaç tümcecikleri ya da grupları

- açık yüklemler ya da yüklemleyici adlar, sıfatlar, adıllar

- eşdizimliler (collocations)

- açık karşılaştırmalar, benzetmeler, eğretilemeler ve ad aktarmaları, abartılar, arıksayışlar (litotes) ve örtmeceler (euphemisms) gibi diğer sözbilimsel figürler

- anıştırmalar (allusions), çağrışımlar (evocations), önvarsayımlar, sezdirimler

Reisigl ve Wodak (2001) yükleme stratejilerini, canlılara, eylemlere ve toplumsal olgulara dilsel olarak özellik yüklemenin bir sonucu ve temel bir süreç olarak nitelendirmektedir. Yükleme, nedensiz bir biçimde kullanılmamakta, çeşitli biçimlerdeki ve öbeklerdeki saklı ideolojileri içermektedir. Aynı zamanda bu strateji, 'biz' ve 'onlar' arasındaki grup içi olumlu ve grup dışı olumsuz yüklemeleri gösteren ikiliği ortaya koymaktadır. En temel düzlemde yükleme, 
belirli toplumsal aktörleri eleştirmek, zayıflatmak ve kötülemek amacıyla kullanılmaktadır (Richardson, 2007, s. 53). Bu çalışmada söylemsel yükleme söylemsel stratejisi, medya söylemi metin türü olan gazete köşe yazılarında incelenmektedir. Bu doğrultuda bir sonraki başlıkta gazete köşe yazısı söylemi ele alınmaktadir.

\section{GAZETE KÖȘE YAZISI SÖYLEMİ}

Karmaşık ve çatışık süreçlerin bir alanı olan medya söylemi, ideolojik süreçleri içerisinde barındırmakta ve bu nedenle medya metinleri toplumsal denetimde ve yeniden üretimde ideolojik bir işlev ortaya koymaktadır (Fairclough, 1995, s. 47). Bir medya metin türü olarak gazete köşe yazıları toplumdaki güncel olaylara yönelik olarak belli bir konu çerçevesinde oluşturulan düşünce dizisidir (van Dijk, 1998). Çoğu kamusal söylemde olduğu gibi, haberler de ideolojilerle doludur. Kitle iletişim araçlarında ideolojilerin ayrıntılı bir incelemesi, ideolojilerin toplumdaki yeniden üretimine 1şı tutmaya katkıda bulunur ve baskın ideolojilerin, farklı (liberale karşı muhafazakar ve popülere karşı seçkin) gazeteler arasındaki bazı farklılıklarla ve beyaz, erkek, orta sınıf, vs. gazetecilerin kurumsal çevredeki konumu ve gücüyle ilişkili olduğunu göstermektedir (van Dijk, 2009, s. 202). Belirli bir haberi iletmek için kullanılan dilsel yapılar söz konusu habere ilişkin yanlı tutumu ortaya koyan bir anlam ağı ortaya koymaktadır. Bu anlam ağ 1 habercinin, köşe yazarının ya da yayın kuruluşunun, iletinin içeriğini, kendi inanç ve değerler dizgesine, diğer bir deyişle ideolojisine ve bunu dilde düzgüleme biçimine göre nasıl çözümlediğini ortaya koymaktadır (Oktar, 2002, s. 39).

İdeolojilerin üretilmesine, yeniden üretilmesine ve değiştirilmesine katk1 sağlayan ve böylece toplumsal bir algı oluşturarak toplumu biçimlendiren bir kurum olan medya, çağdaş dünyada önemli bir role sahiptir. Güce sahip olan toplumsal aktörler metnin birçok özelliğini kullanarak söylemi denetlemektedir ve bu süreçte medya söylemi önemli bir rol oynamaktadır. İdeolojik süreçleri içerisinde barındıran karmaşık ve çatışık süreçlerin bir alanı olan medya söylemi, medya metinleri yoluyla toplumsal denetimde ve yeniden üretimde, ideolojilerin ortaya koyulması işlevini yerine getirmektedir (Fairclough, 1995). Medyada olaylar ve olgular yeni bir dille yeniden oluşturulmakta ve anlaşılır kılınmakta, temsil edilen ideoloji yeniden yapılandırılarak kamuoyuna sunulmaktadır. Bu doğrultuda, haberin konusu olan bir olay, medyanın kullandığı söylemden etkilenerek farklı anlamlara sahip olacak biçimde sunulmaktadır (Devran, 2010, s. 13).

Bir kurum olarak medyada çeşitli gazeteler bulunmaktadır ve bu gazeteler farklı ideolojik görüşlerin medyadaki temsilcilerini oluşturmaktadır. Bu nedenle bir medya metin türü olan gazete köşe yazılarının incelenmesi, sahip oldukları ideolojik sezdirimlerin ortaya koyulması açısından oldukça önemlidir. Gazetelerin işlevi dış dünyada olanlar konusunda okuyucuları bilgilendirmek ve bu süreçte okuyucuların dünyayı kendi bakış açıları doğrultusunda görmelerini sağlamaktadır (Yağcıŏglu, 2002, s. 21). Köşe yazılarının bulunduğu sayfalar, gazetenin kimliğini 
ortaya koymaktadır ve gazetenin siyasi eğilimi tarafindan yönlendirilen bu sayfalar, gazetecilerin düşüncelerini belirtme yetkisine sahip oldukları tek yerdir (WahlJorgensen, 2004, s. 59). Köşe yazıları iyi yapılandırılmış gerekçelerle ileri sürülen savın geçerliliğini kabul etmeleri için okuyucuları etkilemeyi amaçlamakta, ileri sürülen savların geçerliliğine odaklanmakta ve bunları tartışarak eleştirmeye ya da doğruluğunu kanıtlamaya çalışmaktadır (Yağcıŏlu ve Cem-Değer, 2001). Bunun sonucunda bu yazılar kamuoyunun oluşumunu, değişimini, gündemin belirlenmesini, karar verme aşamasını ve başkaca toplumsal ve siyasi olayları etkilemektedir (van Dijk, 1998). Toplumsal süreçlerde önemli role sahip olan bu yazılar, çalışmamızın veritabanını oluşturmaktadır. Bu doğrultuda bir sonraki başlıkta çalışmamızın veritabanına ve yönteme yer verilmektedir.

\section{VERITABANI VE YÖNTEM}

Çalışmamızın veritabanı karşıt ideolojik görüşe sahip Cumhuriyet ve Sabah Gazeteleri'nde yer alan politik içerikli köşe yazılarından oluşmaktadır. Söz konusu gazetelerin seçilmesinin nedeni, Türkiye'deki sol-laik ve sağ-muhafazakar ideolojinin medyadaki temsilcileri olarak nitelendirilmeleridir. Seçilen gazetelerde, yeni baro düzenlemesinin gündeme geldiği ve yoğun bir biçimde tartış1ldığ zaman dilimini içeren 15-26 Haziran tarihleri arasında yayımlanan köşe yazıları incelenmiştir. Söz konusu baro düzenlemesiyle ilgili köşe yazıları içinden her iki gazeteden Basit Rastgele Örneklem (Simple Random Sampling) alma yöntemiyle birer köşe yazısı seçilmiştir. Seçilen yazılar, Mustafa Balbay tarafından yazılan, 23 Haziran tarihinde Cumhuriyet Gazetesi'nde yayımlanan Avukata Yeşil Pasaport... Baroya kırmızı kart! adlı köşe yazısı ve Hilal Kaplan tarafından yazılan, 26 Haziran 2020 tarihinde Sabah Gazetesi'nde yaymlanan Demokratik temsile mi karşısınız, çoğulculuğa mı? adlı köşe yazısıdır.

Gazete köşe yazısı söylemi kapsamında farklı ideolojik yönelimlerin söylemsel boyutlarının belirlenmesi amacıyla veri toplama yöntemi olarak "doküman incelemesi” yöntemi kullanılmıştır. Doküman incelemesi yöntemi, incelenmesi amaçlanan olgulara ilişkin bilgileri içeren yazılı verilerin çözümlenmesini içermektedir (Şimşek ve Yıldırım, 2016, s. 189). Çalışmanın çözümleme yöntemini ise, STY'de yer alan ve çalışmamızın kuramsal bölümünde ele alınan söylemsel stratejiler kapsamındaki 'yükleme' söylemsel stratejisi oluşturmaktadır. Yükleme stratejileri, olumlu ya da olumsuz özelliklerin basmakalıpsal, değerlendirici nitelemeleri ve örtük ve açık yüklemeler aracılığıyla gerçekleştirilmektedir. İdeolojik yönelimelerin söylemsel boyutları, belirli bir sosyopolitik bağlam içinde anlamlandırılmakta ve yorumlanmaktadır. $\mathrm{Bu}$ doğrultuda bir sonraki başlıkta, olayların ve olguların yorumlanmasında belirleyici olan sosyopolitik bağlama yer verilmektedir.

\section{Sosyopolitik İklim}


Çalışmanın veritabanını oluşturan köşe yazıları, Türkiye'de son dönemde iktidar tarafından baro sistemine ilişkin gerçekleştirilmek istenen değişiklikler bağlamında yazılmıştır. Buna göre iktidar, Avukatlık Yasası'nı değiştirmek amacıyla ilgili düzenlemeyi yakın zamanda TBMM'ye getirerek çoklu baro sistemine geçmeyi amaçlamakta, muhalefet ise bu düzenlemeye karşı çıkmaktadır. Söz konusu yeni düzenlemeyle birlikte şehirlerde çoklu baroların kurulabilmesine olanak tanınmakta, 5000'den fazla avukatın bulunduğu illerde 2000 avukatın imzasıyla bir baro daha kurulabilmesinin önü açılmaktır. Bununla birlikte mevcut düzenlemede, barolar temsilde adalet ilkesi gereği, her 300 avukat için 1 delege daha gönderirken yeni düzenlemenin kabul edilmesi durumunda her baro 5000 avukat için yalnızca 1 delege hakkına sahip olmaktadır; dolayısıyla İstanbul, Ankara ve İzmir Baroları ile Anadolu'nun küçük şehirlerindeki baroların delege sayıları eşitlenmekte ve bu sistem, büyük baroların seçimlerdeki etkisinin azaltılması gibi bir sonuca yol açmaktadır.

Baro sistemi değişikliği kapsamında muhalefet, iktidarın, baroların üye sayısından kaynaklı doğal haklarını ortadan kaldırmayı; demokrasiyi, yargı bağımsızlı̆̆ını, insan haklarını gözeten, çevre duyarlılı̆̆ çıkarmayı ve iktidarın uyumlu bir unsuru haline getirmeyi amaçladığını ileri sürmektedir. Bunun yanı sıra, bu düzenlemenin arka planında, başta Türkiye'deki en büyük barolar olan İstanbul, Ankara ve İzmir Baroları olmak üzere bazı baroların iktidara karşıt bir tutum sergileyerek muhalif bir tutum içinde bulunması, bu nedenle iktidarın muhalif baroları kendi varlığına yönelik bir tehdit olarak algilaması yer almaktadır. Bu nedenle iktidar, baroların, muhalefetle birlikte hareket ettiğini ileri sürmekte ve söz konusu baroları iktidar karşıtı tutumları nedeniyle eleştirmektedir. Bir sonraki başlıkta, çalışmanın veritabanını oluşturan yazıların söz konusu sosyopolitik bağlam çerçevesinde ve STY'de yer alan yükleme stratejisi aracıllğıyla çözümlenmesi sonucunda ulaşılan bulgulara ve bu bulguların yorumlanmasına yer verilmektedir.

\section{BULGULAR VE TARTIŞMA}

Çalışmamızın veritabanını oluşturan gazete köşe yazılarının yükleme söylemsel stratejisi kapsamında çözümlenmesi sonucunda, söz konusu yazılarda bazı toplumsal aktörlerin ve olguların olumlu, bazılarının ise olumsuz yükleme niteliğine sahip olduğu ve bu bu yüklemelerin +/- olumlu özelliğinin, yazının yer aldığı gazetenin ideolojik yöneliminden etkilendiği belirlenmiştir. Bu doğrultuda ilk olarak Tablo 2'de Cumhuriyet, ikinci olarak Tablo 3'te Sabah Gazetesi'nde yer alan köşe yazılarında kullanılan yükleme stratejilerine yer verilmektedir:

Tablo 2: Cumhuriyet Gazetesi’nde Yer Alan Köşe Yazısındaki Yüklemeler 


\begin{tabular}{|c|c|}
\hline TOPLUMSAL AKTÖRLER & YÜKLEMELER \\
\hline İktidar (AKP) & $\begin{array}{l}\text {-Yargının bütün kurumları tüketildi, sıra barolara geldi. } \\
\text {-AKP, bu bağımsız, kendi yöneticilerini kendisi seçen örgütlü gücü } \\
\text { istemiyor. } \\
\text {-İşte baroların bu işlevini (yanlış bulduğuna müdahale etme) ortadan } \\
\text { kaldırmak istiyorlar. } \\
\text {-Daha şehre girerken engelleme başladı. } \\
\text {-Sadece baro başkanlarının birer metre arayla yürümesine bile izin } \\
\text { verilmedi. } \\
\text {-Parti-devlet yönetimi } \\
\text {-Barolara kırmızı kart! } \\
\text {-(barolara) Kıymayın... }\end{array}$ \\
\hline Hâkimler ve savcılar & $\begin{array}{l}\text {-Hâkim ve savcıların bağımsız karar vermesi cesaret istiyor. } \\
\text {-En hafifinden sürgünü göze almayı gerektiriyor. }\end{array}$ \\
\hline Avukatlar & -Adaletin kilit taşı \\
\hline Barolar & $\begin{array}{l}\text {-(avukatın) Arkasında baro var. } \\
\text {-Yargının en önemli kurumu } \\
\text {-Bağımsız, kendi yöneticilerini kendisi seçen örgütlü güç. } \\
\text {-I̧slevi mahkeme salonuyla sınırlı değil. } \\
\text {-Baronun görevi sadece avukatların özlük haklarını korumak değil. } \\
\text {-(görevi) Toplumun da her türlü hakkını savunmak, dile getirmek. } \\
\text {-Toplumun vicdanını kanatan her olayda barolar kurumsal olarak “müdahil” } \\
\text { oluyorlar. } \\
\text {-Barolar da önemli ölçüde (yasaların) uygulanmasını denetliyor. } \\
\text {-Yanlış bulduğuna müdahale ediyor. } \\
\text {-Türkiye Barolar Birliği'nin tarihi, hukukun üstünlüğüne dayalı duruşlar } \\
\text { göstermiş sayfalarla doludur. } \\
\text {-Toplumun adalete ulaşma hakkına sahip çıkar. }\end{array}$ \\
\hline TOPLUMSAL OLGULAR & YÜKLEMELER \\
\hline Yeni baro düzenlemesi & $\begin{array}{l}\text {-Bu, yargının üçüncü ayağını da iktidar gölgesine sokma hırsıyla bitirmek } \\
\text { demek. } \\
\text {-Düzenleme geçerse, avukat diyelim ki iktidara yakın bir barodan, dava } \\
\text { nasıl sonuçlanırsa sonuçlansın bu gölge olacak! } \\
\text {-Orada adalet dağıtılmaz, adalet dağılır! }\end{array}$ \\
\hline
\end{tabular}




\begin{tabular}{|l|l|}
\hline Dün (22 Haziran 2020) & $\begin{array}{l}\text {-Tarihi bir gündü. } \\
\text {-Parti-devlet yönetiminin yargının en önemli kurumunu başkente sokmadığı } \\
\text { gündü. }\end{array}$ \\
\hline
\end{tabular}

Tablo 2'de yer verildiği gibi, Cumhuriyet Gazetesi'nde Balbay tarafından yazılan köşe yazısında söylemsel olarak inşa edilen toplumsal aktörler ve olgular bulunmaktadır. Bu doğrultuda söz konusu yazıda söylem aracılığıyla olumlu ve olumsuz biçimde farklı açılardan sunulan "iktidar", "hâkimler ve savcılar", "avukatlar" ve "barolar" gibi toplumsal aktörler; "yeni baro düzenlemesi" ve "dün (22 Haziran 2020)" gibi toplumsal olguların bulunduğu belirlenmiştir. Çalışmamızda, bir zaman aralığına gönderimde bulunan "dün” (22 Haziran 2020) ifadesinin toplumsal bir olgu olarak sınıflandırılmasının nedeni, bu günün bir zaman diliminden öte yazar tarafindan ideolojik sezdirimleri olan bir gün ve tarih olarak betimlenmesidir.

Cumhuriyet Gazetesi'nde yer alan köşe yazısında sunulan toplumsal aktörlerden biri olan iktidar, yalnızca olumsuz yüklemeler aracılığıyla betimlenmiştir. Kılıcının örtükleştirildiği "Yargının bütün kurumları tüketildi, sıra barolara geldi" yüklemesinde eylemin gerçekleştiricisi olarak örtük biçimde iktidara gönderimde bulunulmakta ve eğretilemeli bir yüklem (tüketildi) kullanılarak Türkiye'de AKP'nin yargının bütün kurumlarını kendi çıkarları doğrultusunda kullandığı, sonunu getirdiği, işlevsizleştirdiği ve son olarak baroları da işlevsizleştirmeye çalıştığ ifade edilmektedir. İktidara ilişkin bir diğer yükleme olan "AKP, bu bağımsız, kendi yöneticilerini kendisi seçen örgütlü gücü istemiyor." yüklemesinde açık bir yüklem kullanılarak iktidarın, bağımsız bir niteliğe sahip bir meslek kuruluşu olarak baroları egemenliği altına almak istediği ifade edilerek iktidarın bağımsızlık ve özgürlük karşıtı olduğuna yönelik muhalif görüşlülerce sahip olunan bu genel alg1 yinelenmekte; iktidar, kendi yöneticilerini kendisi seçen örgütlü gücü istememesi nedeniyle demokrasi karşıt1, baskıc1, totaliter olarak sunulmaktadır. "İşte baroların bu işlevini ortadan kaldırmak istiyorlar." yüklemesinde örtük biçimde iktidara gönderimde bulunulmakta; iktidarın, baroların her türlü toplumsal ve yasal meselelerde söz sahibi olmasından rahatsız olduğu ve yeni baro düzenlemesinin, baroların toplumsal ve yasal konulara dahil olmasını engellemeyi amaçladığ 1 sezdirilmektedir. "Daha şehre girerken engelleme başladl." ve "Sadece baro başkanlarının birer metre arayla yürümesine bile izin verilmedi." yüklemelerinde söz konusu eylemlerin kılıcısı olarak iktidara gönderimde bulunulmakta, yeni baro düzenlemesine karşı yapılan gösteriler iktidar baskıcı, demokrasi karşıtı ve hak ve özgürlükleri sınırlandıran bir yönetim olarak olumsuz yönde betimlenmektedir.

Söz konusu yazıda iktidar, "parti-devlet" sifatıyla nitelenmekte; bu doğrultuda hükümet ile AKP arasındaki sınırın ortadan kalktığ 1 ve diğer yüklemelere koşut olarak AKP'nin her türlü demokratik ve yasal unsurlara karşı bir yönetim olduğu yinelenmektedir. AKP'ye yönelik bir diğer yükleme olan 
"Barolara kırmızı kart!" yüklemesi, futbol kaynak alanından yararlanılarak oluşturulan bir eğretilemedir. Kırmızı kart, kurallara uymayan oyuncunun cezalandırılması amacıyla oyun dışında bırakılmasıdır. Bu eğretileme aracılığıyla yazar, AKP'nin kendisine boyun eğmeyen baroları cezalandırdığını ve 'oyun dışında' bırakmayı amaçladığını bildirmektedir. Baroların kurallara uymaması sonucunda oyun dışında bırakılması, iktidarın baroları bir engel olarak gördüğünü ve bu engeli ortadan kaldırmayı, baroların direnişini kırmayı amaçladığını sezdirmektedir. İktidara ilişkin olarak olumsuz bir betimleme niteliğindeki son yükleme olan "Kiymayın..." yüklemesiyle iktidara seslenen yazar, iktidarın barolara "kıyacağını" önvarsaymaktadır. "Kıy-", Türk Dil Kurumu Güncel Türkçe Sözlük kapsamında "Acımayarak büyük bir kötülük etmek, zulmetmek" anlamındadır. Kullanımdaki anlamıyla söz konusu sözcük, iktidarın barolara zulmettiğini ve bu nedenle bir "zalim" olduğunu sezdirmektedir.

Balbay'ın yazısında bir diğer toplumsal aktör olan hâkimler ve savcılar "Hâkim ve savclların bağımsız karar vermesi cesaret istiyor." yüklemesinde iktidarın kararlarını uygulayan bağımlı aktörler olarak betimlenmekte, iktidardan bağımsız hareket etmeleri durumunda söz konusu yarg1 mensuplarının yaptırımlarla karşılaşacağ 1 sezdirilmektedir. Aynı biçimde "En hafifinden sürgünü göze almayl gerektiriyor." yüklemesiyle de hakim ve savcıların iktidardan bağımsız karar vermeleri durumunda cezalandırılacakları ifade edilmektedir. $\mathrm{Bu}$ nedenle hakimler ve savcılar, iktidar baskısına karşı koymak isteyen ancak bunu göze alamayan, bu baskıya boyun eğmek zorunda kalan "edilgen" ve "korkak" ediciler olarak olumsuz biçimde betimlenmiş̦tir. Buna karşın Balbay bir diğer toplumsal aktör olan avukatları olumlu olarak betimlemekte; mimarlık kaynak alanından yararlanarak avukatları "Adaletin kilit taşı" eğretilemesiyle nitelemektedir. Kilit taşı, mimarlıkta taş örgüsünün kilitlenmesini sağlayan ve genellikle bir tonoz, bir kemer ya da bir kubbenin en yüksek noktasında bulunan taşa verilen addır. Bu doğrultuda söz konusu eğretilemeyle avukatların adalet sistemini ayakta tutan en önemli ve etkili yarg1 aktörü olduğu ifade edilmektedir. Aynı zamanda yazar diğer yargı kurumlarının iktidardan bağımsız karar veremediklerini ileri sürmesi ve avukatları adaletin kilit taş1 olarak nitelemesi nedeniyle avukatlara, adaleti sağlamakla sorumlu tek yargı kuruluşu olma gibi bir görev yüklemektedir.

Yazıda barolara ilişkin tüm yüklemeler baroları olumlu olarak betimlemektedir. "(avukatın) Arkasında baro var." yüklemesinde "arkasında" ifadesiyle yönelimsel bir eğretileme gerçekleştirilmektedir. Kültürel olarak birinin ya da bir şeyin arkasında olmak, onun savunulduğu ve desteklendiği anlamına gelmektedir. $\mathrm{Bu}$ nedenle bu eğretileme baroların, üyesi olan avukatları her durumda savunduğunu ve desteklediğini belirtmektedir. "Yarginın en önemli kигити" ad öbeğiyle Balbay barolara önem yükleyerek, onları diğer yargı kurumlarından ve kuruluşlarından üstün tuttuğunu göstermektedir. "Bağımsız, kendi yöneticilerini kendisi seçen örgütlü gụ̈ç" sıfat yapılanmasılyla baroların demokratik, belirli bir amaç çerçevesinde bir araya gelen, bağımsız, diğer bir 
deyişle hiçbir yasa dışı müdahaleye geçit vermeyen kuruluşlar olduğu belirtilmekte ve en temelde bir "güç" oldukları ifade edilerek bu kuruluşların toplumu ilgilendiren her konuda etkili olduğu sezdirilmekte ve iktidar karşısında baroların mevcut durumu meşrulaştırılmaktadır.

Türkiye'de son dönemde barolar, toplumsal konularda iktidara karşıt görüş bildirmekte, bu nedenle iktidarla karşı karşıya gelmekte ve iktidar baroların yalnızca işini yapması gerektiğini ifade etmektedir. Buna yanıt olarak Balbay "İslevi mahkeme salonuyla sinırlı değil." yüklemesinde "sınırlı değil" yüklemleyici sıfat ve "Görevi sadece avukatların özlük haklarını korumak değil." ve "Görevi toplumun da her türlü hakkını savunmak, dile getirmek." eylemlik tümceciği işlevindeki yüklemeler ile baroların toplumsal konularda söz sahibi olmasına dayanak sağlamakta ve bu kuruluşların eylemlerini gerekçelendirmektedir. Aynı biçimde, "Toplumun vicdanını kanatan her olayda barolar kurumsal olarak müdahil." yüklemesindeki müdahil yüklemleyici sıfat ve "Yanlış bulduğuna müdahale ediyor." yüklemesindeki müdahale ediyor açı yüklem yoluyla baroların toplumsal konularda etkin bir rol oynadığı, aynı zamanda "toplumun vicdanını kanatan her olayda" ifadesiyle baroların toplumun hakkını savunan vicdanlı bireylerce yönetildiği, toplumun yanlış bulduğunu yanlış bulan kuruluşlar olduğu ileri sürülerek bu yüklemenin altında "barolar eşittir toplum" iletisi yatmaktadır. "Toplumun adalete ulaşma hakkına sahip çıkar." yüklemesiyle baroların adil olduğu ve herkes için adalet sağladığı belirtilerek toplumsal rolüne ve önemine vurgu yapılmaktadır. Barolara ilişkin tüm bu yüklemeler, baroların toplumsal konulardaki etkin rolünü haklı çıkarmayı amaçlamakta ve baroları olumlu biçimde betimlemektedir.

Balbay, "Yasaların uygulanmasını denetliyor." yüklemesiyle baroların, iktidarın bir denetim mekanizması olduğunu ifade etmekte ve baroların muhalif tavrını doğallaştırmakta ve gerekçelendirmektedir. Bununla birlikte "Türkiye Barolar Birliği’nin tarihi, hukukun üstünlüğüne dayalı duruşlar göstermiş sayfalarla doludur." yüklemesindeki "doludur" eğretilemeli yüklem yoluyla barolar kapsamında ele alınabilecek bir üst meslek kuruluşu olan TBB'nin geçmişi, bağımsız ve hukuku her şeyden üstte tutan bir kuruluş olarak olumlu biçimde betimlenmektedir. Bu aşamada dikkat çeken nokta, tarihteki TBB'nin hukuka verdiği önemden söz edilmesine karşın günümüzdeki TBB'nin rolünden söz edilmemesidir. Bunun nedeninin, günümüzde TBB'nin mevcut başkanı Metin Feyzioğlu'nun, iktidar partisi AKP ile olan iyi ilişkileri, iktidarla birlikte hareket etmesi ve bu ilişkilerin muhalefet tarafından onaylanmaması olduğu söylenebilir.

Toplumsal aktörlerin sonrasında yazıdaki toplumsal olgular incelendiğinde, muhalif görüşlü bir gazete olan Cumhuriyet'te iktidar tarafından ileri sürülen yeni baro düzenlemesi teklifinin olumsuz olarak betimlendiği görülmektedir. " $B u$, yargının ü̧̈üncü ayağını da iktidar gölgesine sokma hırsiyla bitirmek demek." eylemlik tümceciğiyle düzenlemenin amacına ve sonuçlara ilişkin bir betimleme yapılmakta; düzenlemenin amacının, baroları iktidarın bir alt kuruluşu durumuna 
getirmek amacıyla yargının sonunu getirmek olduğu ifade edilmektedir. "Yargının üçüncü ayağını da" ad öbeğindeki bağlaç ise (da), yargının diğer ayaklarının da iktidara bağımlı olduğu önvarsayımını içermektedir. Buna ilişkin olarak "Düzenleme geçerse, avukat diyelim ki iktidara yakın bir barodan, dava nasıl sonuçlanırsa sonuçlansın bu gölge olacak!" yüklemesindeki "gölge olacak" eğretilemeli yüklemi, bu düzenlemenin, eşitsizliği doğuracağını ve davaların sonuçlanmasında ideolojik görüşlerin adaletin önüne geçeceğini ifade etmektedir. Son olarak yeni baro düzenlemesinin olumsuz olarak sunulduğu bir diğer yükleme olan "Orada adalet dăğtılmaz, adalet dağılır!" yüklemesinde varlıksal bir eğretileme yoluyla adaletin sağlanamayacağı, haklı ve haksız arasındaki ayrımın ortadan kalkacağı ve güçsüzleştirileceği ifade edilmektedir. Balbay aynı zamanda "dün" adıyla 22 Haziran 2020 tarihine gönderimde bulunarak bu-günü "Tarihi bir gün” ve "Parti-devlet yönetiminin yargının en önemli kurumunu başkente sokmadığı gün." olarak olumsuz çağrışıma sahip bir anlam ve önem yükleyerek bu tarih üzerinden iktidarı olumsuz olarak betimlemektedir.

Tablo 3: Sabah Gazetesi'nde Yer Alan Köşe Yazısındaki Yüklemeler

\begin{tabular}{|c|c|}
\hline TOPLUMSAL AKTÖRLER & YÜKLEMELER \\
\hline Ana Muhalefet & $\begin{array}{l}\text {-Demokratik temsile karşı. } \\
\text {-Çoğulculuğa karşı. } \\
\text {-Kaftancıoğlu, İstanbul Barosu'na avukatı şikayet etti. } \\
\text {-Ana muhalefet ilk dakikadan 'istemezük' demeye başladı bile. }\end{array}$ \\
\hline İktidar (AKP) & $\begin{array}{l}\text {-Buna rağmen AK Parti, tüm muhalefet partilerini ziyaret etti ve üç farklı } \\
\text { formül sundu. }\end{array}$ \\
\hline Barolar & $\begin{array}{l}\text {-1960 darbesinden sonra yapılan } 61 \text { Anayasası ile vesayetin taşıyıcı } \\
\text { ayaklarından biri olma vazifesine sahip. } \\
\text {-S ıklıkla temsil kabiliyetlerinin sınırlarını çiğneyip geçiyorlar. } \\
\text {-On yıllardır bu barolarda köşe başlarını tutmakta olanlar. } \\
\text {-Bu temsilin gereğini yapmak bir yana, arzu ettikleri ideolojik görüşe göre } \\
\text { açıklama yayınlayıp inisiyatif alabiliyorlar. }\end{array}$ \\
\hline İstanbul Barosu & $\begin{array}{l}\text {-Faşist } \\
\text {-Adnan Menderes ve arkadaşlarını savunacak avukatları barodan atmakla } \\
\text { tehdit edebiliyor. } \\
\text {-28 Şubat sürecinde "Başörtülüler giremez" pankartını asan İstanbul } \\
\text { Barosu... } \\
\text {-Yıllarca başörtülü meslektaşlarını cadı avına tabi tutup stajyer olarak bile } \\
\text { kabul etmemeleri de... } \\
\text {-Baro da tıpış tıpış avukattan savunma istedi. } \\
\text {-Meslektaşını korumak yerine, ideolojik 'yoldaş'_ını korudu. }\end{array}$ \\
\hline
\end{tabular}


Danlş, $P$.

DEÜ SBE Dergisi, Cilt: 23, Sayl: 3

\begin{tabular}{|c|c|}
\hline Ankara Barosu & $\begin{array}{l}\text {-On binlerce avukatı temsilen Kur'an-1 Kerim'i "çağlar ötesinden gelen bir } \\
\text { ses" diye aşağılayabildi. }\end{array}$ \\
\hline İktidara yakın avukat & $\begin{array}{l}\text {-En son sadece avukatlık mesleğinin gereğini yaparak müvekkili İletişim } \\
\text { Başkanı Fahrettin Altun adına Canan Kaftancıoglu hakkında suç } \\
\text { duyurusunda bulunan. } \\
\text {-Başına gelenleri gördük. }\end{array}$ \\
\hline Tabipler ve Mimarlar Odası & $\begin{array}{l}\text {-Tabipler Odası ve Mimarlar Odası gibi ideolojik sekteryaen diğer } \\
\text { yapılanmalar }\end{array}$ \\
\hline TOPLUMSAL OLGULAR & YÜKLEMELER \\
\hline Temsil & -Avukatlık mesleğinin özü olan kutsal bir görev. \\
\hline 1961 Anayasası & -1960 darbesinden sonra yapılan. \\
\hline Yeni baro düzenlemesi & $\begin{array}{l}\text {-Yerleşik baroları ortadan kaldıran bir durum söz konusu değil. } \\
\text {-Avukatlık mesleğini icra edenlerin temsilini daha çoğulcu ve adil biçimde } \\
\text { yansıtacak bir teklif söz konusu. } \\
\text {-Yeni baro düzenlemesini destekliyor ve artırıyorum: Benzer } \\
\text { düzenlemelerin, ideolojik sekteryan diğer yapılanmalar için de getirilmesini } \\
\text { talep ediyorum. }\end{array}$ \\
\hline
\end{tabular}

Tablo 3'te yer verildiği gibi, Sabah Gazetesi'nde Kaplan tarafından yazılan köşe yazısı, Balbay'ın yazısına benzer olarak söylemsel olarak inşa edilen toplumsal aktörleri ve olguları içermektedir. Söz konusu yazıda söylem aracılığıyla olumlu ve olumsuz biçimde farklı açılardan sunulan "muhalefet", "iktidar", "barolar", "İstanbul Barosu", "Ankara Barosu", "İktidara yakın avukat" ve "Tabipler ve Mimarlar Odası" gibi çok sayıda toplumsal aktörün ve "temsil”, "1961 Anayasası", ve "yeni baro düzenlemesi" gibi toplumsal olguların söylemsel olarak inşa edildiği belirlenmiştir.

Sabah Gazetesi'nde yer alan köşe yazısında sunulan toplumsal aktörlerden biri olan muhalefet, yeni baro düzenlemesine karşı çıkması nedeniyle demokratik temsil ve çoğulculuk karşıtı biçiminde nitelenmekte ve söz konusu düzenlemenin demokratik ve çoğulculuğa önem veren bir düzenleme olduğu önvarsayılmaktadır. Cumhurbaşkanlığı İletişim Başkanı Fahrettin Altun'un, ana muhalefet partisi 
CHP'nin İstanbul İl Başkanı görevindeki Canan Kaftancıoğlu hakkında suç duyurusunda bulunmasına ilişkin olarak "Kaftancioğlu, İstanbul Barosu'na avukatı şikayet etti." yüklemesiyle baroların ana muhalefet partisi CHP ile birlikte ve hareket ettiği, iktidara karşıt bir tutum sergilediği ve bu açıdan bağımsız bir kuruluş olmadığ 1 ifade edilmektedir.

Muhalefetin olumsuz betimlenmesine yönelik bir diğer yükleme, yeni baro düzenlemesine ilişkin "Ana muhalefet ilk dakikadan 'istemezük' demeye başladı bile." yüklemesiyle gerçekleştirilmektedir. Bu yüklemedeki “istemezük" sözcüğü, yalnızca ideolojik çatışma nedeniyle yapılan her iyi işe karşı çıkmayı çağrıştırmaktadır. Bu doğrultuda Kaplan, iktidarın yeni baro düzenlemesinin doğru bir düzenleme olduğunu, ancak yalnızca ideolojik gerekçelerle muhalefet tarafindan kabul görmediğini önvarsaymaktadır. Muhalefeti olumsuz olarak betimleyen Kaplan, "Buna rağmen AK Parti, tüm muhalefet partilerini ziyaret etti ve üç farklı formül sundu." yüklemesiyle iktidarın muhalefet partilerinin görüşlerini önemsediğini ve uzlaşmacı bir tavır sergilediğini belirterek iktidarı olumlu olarak betimlemektedir.

Kaplan'ın yazısında barolar tüm yüklemelerde olumsuz olarak betimlenmektedir. Baroları ilk olarak tarihsel boyutta ele alan Kaplan "1960 darbesinden sonra yapılan 61 Anayasası ile vesayetin taşıyıcı ayaklarından biri." yüklemleyici adı yoluyla baroları darbe zihniyetinin temsilcisi ve devamı olarak nitelendirmektedir. "Siklıkla temsil kabiliyetlerinin sinırlarını çiğneyip geçiyorlar." yüklemesiyle günümüzde baroların, yükümlülüklerinden daha fazlasına yeltendiği ifade edilerek (çoğunlukla) hukuk dış1 girişimlerde bulunduğu sezdirilmektedir. Buna ilişkin bir diğer olumsuz betimleme, "Bu temsilin gereğini yapmak bir yana, arzu ettikleri ideolojik görüşe göre açıklama yayınlayıp inisiyatif alabiliyorlar." yüklemesiyle gerçekleştirilmekte; temsilin gereğini yapmak bir yana ifadesiyle baroların görevini yapmadığı, "arzu ettikleri ideolojik görüşe göre açıklama yayınlayıp" ifadesiyle görevi dışında ideolojik çıkarlar peşinde koştukları, "inisiyatif alabiliyor" ifadesiyle bu kuruluşların bağımsız biçimde ve kuralların dışına çıkarak karar verdiği ifade edilmekte ve otoriteyi göz ardı ettiği sezdirilmektedir. "On yıllardır bu barolarda köşe başlarını tutmakta olanlar" ad öbeğiyle, baroların karşıt görüşlü kişilerce ele geçirildiği ve zapt edildiği sezdirilmekte ve baroların görevleri dışına çıkarak yaptığı eylemlerin ideolojik temelli eylemlerin köşe başını tutan kişilerce gerçekleştirildiği ifade edilmektedir.

Balbay'ın yazısında herhangi bir şehrin barosuna ilişkin bir yükleme bulunmamasına, en temelde bir kuruluş olan barolardan söz edilmesine karşın Kaplan, İstanbul ve Ankara Baroları'na ayrı başlık açmakta ve her iki baroyu da olumsuz olarak betimlemektedir. İlk olarak İstanbul Barosu'nu konu alan Kaplan, geçmişte yaşanan önemli politik olaylara gönderimde bulunmakta, "Adnan Menderes ve arkadaşların savunacak avukatları barodan atmakla tehdit etti" yüklemesindeki tehdit etti yüklemiyle İstanbul Barosu'nun o dönemlerde de ideolojik bir yapılanma olduğunu ve hukuk ve demokrasi karşıtı eylemler yerine 
getirdiğini ifade ederek tarihte bu baroyu "Faşist" olarak betimlemektedir. Türk politika tarihinde gericilik karşıtı kararlarıyla bilinen, sağ-muhafazakar kesimin post-modern darbe olarak adlandırdığ 28 Şubat sürecindeki baroların politik duruşundan söz eden Kaplan, baroları "Başörtülüler giremez pankartını asan" ilgi tümceciğiyle ve "Yıllarca başörtülü meslektaşlarını cadı avına tabi tuttu" yüklemesindeki "Fikirleri topluma tehdit olarak görülen kimselere karşı düzenlenen kampanya" anlamına gelen "cadı avı" eğretilemesiyle betimlemekte; baroların geçmişte de günümüzde olduğu gibi başörtülüleri bir tehdit olarak gördüğü, başörtülüleri toplumdan dışlamayı amaçladığı ileri sürülerek en temelde baroların sağ-muhafazakar ideolojiye ve böylelikle İslam dinine karşıt olduğu belirtilmektedir.

Kaplan "Tıpış tıpış avukattan savunma istedi" yüklemesindeki belirteç işlevine sahip tıpış tıpış ikilemesiyle ve "Meslektaşını korumak yerine, ideolojik 'yoldaş'ını korudu" yüklemesiyle İstanbul Barosu'nun CHP'nin buyruklarını uyguladığını, Kaftancıoğlu hakkında suç duyurusunda bulunan avukata yönelik baro tarafından bir baskı uygulandığını, baronun meslektaşına sahip çıkmak yerine ideolojik çıkarlarının örtüşmesi nedeniyle Kaftancıoğlu'nu savunduğunu ifade etmektedir. $\mathrm{Bu}$ doğrultuda Kaplan baronun, muhalefet yanlısı olduğunu ve ideolojik amaçlar güderek ayrımcılık yaptığını sezdirmektedir. Son dönemlerde Diyanet'in, zinaya ve eşcinselliğe ilişkin yaptı̆ğ açıklamalara karşı olarak Ankara Barosu tarafından yapılan açıklamalarda Diyanet İşleri Başkanı Ali Erbaş, "sesi çağlar öncesinden gelen şahıs" olarak nitelendirilmiştir. Buna ilişkin olarak, İstanbul Barosu'nun yanı sıra Ankara Barosu'na da gönderimde bulunan Kaplan, "Diyânet'in zina ve eşcinselliğin haram olduğunu belirttiği hutbesine tepki veren" ilgi tümceciği ve "On binlerce avukatı temsilen Kur'an-ı Kerim'i "çağlar ötesinden gelen bir ses" diye aşağılayabildi" yüklemesindeki "çağlar öncesinden gelen bir ses" ve "aşağılayabildi" ifadeleri yoluyla Ankara Barosu'nu dini emirlere karşı çıkan bir kuruluş olarak betimlemektedir. Kaplan, Diyanet İşleri Başkanı'nın fetvaları ile Kur'an-1 Kerim'in emirlerini özdeşleştirmekte, bu nedenle Ankara Barosu tarafından Diyanet İşleri Başkanı'na ilişkin ileri sürülen ifadeyi (sesi çağlar öncesinden gelen şahıs) Kur'an-1 Kerim'e yapılan bir hakaret olarak betimlemektedir. Bir diğer toplumsal aktör olan iktidara yakın avukat, Kaplan tarafindan olumlu betimlenmekte; "Sadece avukatlk mesleğinin gereğini yaparak müvekkili Illetişsim Başkanı Fahrettin Altun adına Canan Kaftancıoğlu hakkında suç duyurusunda bulunan" ve "Başına gelenleri gördük" yüklemeleriyle avukatın farklı bir amaç gütmeden yalnızca işini yaptığı, ancak CHP tarafından mağdur edildiği ileri sürülmektedir. Baroların yanı sıra farklı kuruluşlardan da söz eden Kaplan, "ideolojik sekteryen diğer yapılanmalar" ifadesiyle Tabipler ve Mimarlar Odası'nın da ideolojik amaçlara sahip kuruluşlar olduğunu ifade etmekte ve "diğer" ifadesiyle baroların da ideolojik sekteryan yapılanmalar olduğunu önvarsaymaktadır.

Toplumsal aktörlerin sonrasında yazıdaki toplumsal olgular incelendiğinde, iktidara yakın görüşlere sahip bir gazete olan Sabah'ta yer alan köşe yazısında 
barolara karşıt bir duruş sergilenmesine karşın avukatlığın temsil ile ilişkilendirildiği, temsilin "Avukatlık mesleğinin özü olan kutsal bir görev" olarak nitelendiği ve böylelikle karşı çıkılan unsurun demokrasinin ve hukukun bir göstergesi olan "temsil”" olgusu olmadığı, yalnızca baroların ideolojik girişimlerine ve eylemlerine karşı çıkıldığı sezdirilmektedir. Aynı zamanda toplumsal olgular çerçevesinde 1961 Anayasası, "1960 darbesinden sonra yapılan" sifatıyla nitelenerek anayasanın bir darbe anayasası olduğu vurgulanmaktadır. $\mathrm{Bu}$ anayasanın olumsuz betimlenmesinin temelinde darbe anayasası olmasının yanı sıra, aynı zamanda yapım sürecinde CHP'nin aktif rol oynaması yattığ 1 söylenebilir. Öte yandan yeni baro düzenlemesine ilişkin olumsuz bir betimlemenin yapıldığı yükleme bulunmamakta, tüm yüklemeler bu düzenlemeyi olumlu olarak betimlemektedir. "Yerleşik baroları ortadan kaldıran bir durum söz konusu değil" yüklemesiyle Kaplan, yeni düzenlemenin sanıldığı kadar köklü olmadığını ileri sürerek yeni düzenlemeye karşı olan görüşü ikna etmeye çalışmakta ve düzenlemeyi desteklediğini sezdirmektedir. İktidar tarafından ileri sürülen bu teklifi "Avukatlık mesleğini icra edenlerin temsilini daha çoğulcu" ve "adil biçimde yansitacak bir teklif" olarak niteleyerek bu düzenleme ile demokrasinin ve adaletin en iyi biçimde yerine getirileceğini ifade eden Kaplan, "Yeni baro düzenlemesini destekliyor ve artırıyorum: Benzer düzenlemelerin, ideolojik sekteryen diğer yapılanmalar için de getirilmesini talep ediyorum." ifadeleriyle yeni düzenlemeye ilişkin açıkça görüş belirterek bu düzenlemeyi desteklediğini açık bir biçimde ifade etmektedir.

Cumhuriyet Gazetesi'nde yer alan köşe yazısında "iktidar" ve "hakimsavcılar" olumsuz, avukatlar olumlu olarak betimlemektedir. Yazar iktidarı hukuk, bağımsızlık ve demokrasi karşıtı, totaliter, baskıcı, zalim; hakim ve savcıları iktidara bağımlı ve korkak olarak betimlemektedir. Buna karşın "avukatlar", hakim ve savcıların tersine adaletin tek savunucusu ve adaleti sağlayacak tek bağımsız kesim olarak nitelenmektedir. Söz konusu yazıda yer alan son toplumsal aktör olan "barolar"; bağımsız, demokratik, toplumsal sorunlara duyarlı ve toplumdaki adaleti sağlayan, hukukun üstünlüğünü savunan ve iktidarı denetleyen kuruluşlar olarak ve olumlu biçimde betimlenmektedir. Toplumsal olgular kapsamında "yeni baro düzenlemesi" ve "dün" (22 Haziran 2020) gibi toplumsal olguları olumsuz olarak betimleyen yazar, yeni baro düzenlemesinin, yargının son bağımsız kuruluşunu bitirmek, hukuku tamamen ortadan kaldırmak olduğunu ve adaletin sağlanmasını engelleyeceğini ifade etmektedir. Avukatların yürüyüşünün iktidar tarafindan engellendiğini ileri süren Balbay, söz konusu engellemenin gerçekleştiği güne “dün" ifadesiyle gönderimde bulunmakta, 22 Haziran'1 Türkiye'nin hukuk ve demokrasi tarihindeki kara bir gün olarak niteleyerek olumsuz biçimde betimlemektedir.

Cumhuriyet Gazetesi yazarı Balbay'ın tersine Sabah Gazetesi yazarı Kaplan, yazısında toplumsal aktör olarak muhalefetten söz ederek muhalefeti demokrasi ve çoğulculuk karşıtı, baskıcı, ilerlemeye karşı olarak nitelemektedir. Balbay tarafindan olumsuz olarak betimlenen iktidar, söz konusu yazar tarafindan 
uzlaşmacı olarak olumlu yönde nitelenmektedir. Yazısında barolara önemli bir yer ayıran Kaplan, buna ilişkin tüm yüklemelerinde baroları olumsuz olarak betimlemekte; bu kuruluşların görevini yapmayan, ideolojik meselelere karışan, faşist, ideolojik ortaklarını savunan, ayrımcı ve aynı zamanda dini değerlere karşıt yapılanmalar olduğunu vurgulamaktadır. Bununla birlikte tıpkı iktidar gibi olumlu olarak betimlenen bir diğer aktör olan iktidara yakın avukat da yalnızca mesleğini yapan, ancak ana muhalefet partisi tarafindan haksızlığa uğrayarak mağdur edilen bir aktör olarak betimlenmiştir. Yazar yazısında Tabipler ve Mimarlar Odası gibi kuruluşlara da yer vermekte,-- bu kuruluşları barolara benzeterek bunların da tıpkı barolar gibi 'ideolojik sekteryen' yapılanmalar olduğunu ifade etmekte ve bu yolla olumsuz bir betimleme yapmaktadır. Toplumsal olgular kapsamında temsile önem verdiğini belirten ve bu sayede demokrasi karşıtı olmadığını örtük olarak belirten yazar, hazırlanmasında CHP'nin öncü olduğu 1961 Anayasası'nı darbe sonrası yapılan anayasa olarak nitelendirerek olumsuz olarak betimlemektedir. Balbay tarafindan olumsuz olarak betimlenen yeni baro düzenlemesi Kaplan tarafindan akla yatkın, köklü olmayan, daha adil ve çoğulcu temsili sağlayacak bir düzenleme olarak nitelenmekte ve Kaplan açık bir biçimde bu düzenlemeyi desteklediğini ifade etmektedir.

\section{SONUÇ}

İdeolojinin ortaya çıkarılması, salt dilsel birimleri incelemekle değil söylemi ve karmaşık toplumsal olguları incelemekle gerçekleşmektedir. Söylem ile toplumsal sürecin diğer unsurları arasındaki ilişkiler, belirli yaklaşımlar çerçevesinde incelenmektedir. ESÇ'deki önemli yaklaşımlardan olan STY'de söylem, toplumsal bir kılg1 olarak nitelendirilmekte ve, söylemsel ve söylemsel olmayan davranışlar üreterek bunlar tarafından yeniden üretilmektedir. Söylemin ideolojik boyutunun etkin bir rol oynadığ ideolojik sezdirimlere sahip en önemli metin türlerinden biri gazete köşe yazılarıdır. Bu çalışmada gazete köşe yazısı söylemi, STY yaklaşımı kapsamında yer alan stratejilerden olan yükleme çerçevesinde incelenmekte ve aynı gerçekliğin farklı ideolojik görüşe sahip yazarlar tarafindan nasıl ortaya koyulduğunun, söylemin farklı ve karşıt ideolojiler tarafından nasıl biçimlendirildiğinin ortaya koyulması amaçlanmaktadır.

Çalışmamız kapsamında karşıt ideolojik yönelime sahip gazetelerdeki köşe yazılarında yer alan yükleme stratejilerinin çözümlenmesi ile elde edilen bulguların incelenmesi sonucunda, karşıt ideolojik yönelime sahip gazetelerin yazarlarının yeni baro düzenlemesine ilişkin karşıt bir tutum ortaya koyduğu belirlenmiş ve bu açıdan ideolojilerin, söylemde yer alan yükleme stratejileri aracılı̆̆ıyla ortaya konan tutum ile doğru orantılı olduğu sonucuna ulaşılmıştır. Diğer bir deyişle, aynı gerçeklik, söylemle dolayımlanan ve farklı tutumlarla sonuçlanan karşıt ideolojilerin yansımasıdır. Çalışmanın sonuçları sosyopolitik iklim çerçevesinde yorumlandığında; iktidara yakınlığı ile bilinen Sabah Gazetesi’nde yer alan köşe yazısında yeni baro düzenlemesini ileri süren iktidarla koşut bir tutum öne 
çıkmakta ve söz konusu yazıda bu değişikliğe ilişkin olumlu yükleme stratejileri kullanmakta; muhalefete yakınlığı ve iktidar karşıtı duruşu ile bilinen Cumhuriyet Gazetesi'nde yer alan köşe yazısında ise bu değişikliğe karşı çıkan muhalif kesimle uyumlu bir tutum yer almakta; bu yazıda yeni baro düzenlemesine ilişkin olumsuz yükleme stratejileri yer almaktadır. Öte yandan, Sabah Gazetesi bünyesindeki yazıda bu değişikliğe karşı çıkanlar olumsuz yükleme stratejileri ile sunulurken Cumhuriyet Gazetesi'nde yer alan yazıda söz konusu değişikliğe karşı duruş sergileyen kesim olumlu yükleme stratejileri ile sunulmaktadır. Bu açıdan STY, grup içinin olumlu, grup dışının ise olumsuz olarak betimlenmesine yönelik bir yaklaşım sunmakta; STY'de 'olumlu biz', 'olumsuz onlar' sunuşunu içeren, kimliğin oluşumuna ve içlemenin/dışlamanın gerekçelendirilmesine ve meşrulaştırılmasına temel oluşturan beş tür söylemsel stratejiden biri olan yüklemenin incelenmesi yoluyla olumlu ya da olumsuz özelliklerin kalıpyargısal, değerlendirici nitelemeleri ortaya koyulmakta, toplumsal aktörlerin, olguların ve olayların farklı biçimde betimlenmesine kaynak oluşturan ideolojiler görünür kılınmaktadır. Bu açıdan sosyopolitik bağlam, her ikisi de ulusal günlük gazetede yer alan ikiköşe yazısında tamamıyla karşıt tutum sergilenmesini ve söz konusu tutum yoluyla okuyucuyu ikna etme çabasını anlamlı kılmaktadır.

Çalışmanın sonuçları, farklı ideolojiler tarafindan farklı tutumlar sergileneceği varsayımı açısından beklenen ve doğal bir sonuç olmakla birlikte aynı zamanda medya söyleminin kurucu ve inşa edici rolüne ilişkin kanıt niteliğindedir; medya söylemi, ideolojilerden etkilenmekle birlikte aynı zamanda bireylerin bilişsel dizgelerinin ürünü olan ideolojilere etki etme, onları değiştirme ya da pekiştirme görevini üstlenmektedir. Bu sonuç, medya toplumsal alanında gazetecilerin hedef kitleyi kendi görüşleri ve ideolojileri doğrultusunda ikna etmeye çalıştığını ve bu açıdan medya söyleminde dilin, eylemsel bir nitelik kazandığını ortaya koymaktadır. Tüm bunların yanı sıra, karşıt tutumların söylem yoluyla ortaya konması, medya söyleminin, gücün elde edilmesine yönelik çatışma ve mücadele alanı olduğunu göstermektedir. Medya söylemi kapsamında ortaya konan farklı tutumlar, söylemin farklı ideojiler tarafından denetlenme özelliğine ilişkin bir gösterge niteliğindedir. Bununla birlikte, aynı gerçekliğe yönelik farklı tutumlar, sözü edilen gerçekliğin meşrulaştırılmasına ya da meşruiyetinin giderilmesine yönelik bulunulan ve ideolojilerle güdülenen sosyo-politik bir girişim özelliği taşımakta ve söylemin denetleme özelliğini ön plana çıkarmaktadır. $\mathrm{Bu}$ açıdan söz konusu gerçeklik, nedenlerinin ve sonuçlarının ideolojilere uygunluğu çerçevesinde yükleme stratejileri yoluyla gerekçelendirilmekte ya da bu gerçekliğe karşı çıkılmakta; karşıt tutumların, bir yandan ikna etme görevi görürken öte yandan bu çatışkıdan beslenen ideolojiler için yeniden üretim mekanizması ortaya koyduğu görülmektedir.

\section{KAYNAKÇA}


Blommaert, J. (2005). Discourse. Cambridge: Cambridge University Press.

Bloor M. ve Bloor, T. (2007). The practice of critical discourse analysis. Great Britain: Hodder Arnold.

Büyükkantarcıŏlu, N. (2006). Söylemden ideolojiye: Eleştirel söylem çözümlemesi. A. Kocaman (Haz.), Dilbilim: Temel Kavramlar, Sorunlar, Tartışmalar içinde (ss. 101-113). Ankara: Dil Derneği Yayınları.

Devran, Y. (2010). Haber söylem ideoloji. İstanbul: Başlık Yayın Grubu.

Ercan, G. S. ve Danış P. (2019). Söylem, söylem çözümlemesi ve eleştirel söylem çözümlemesi: Tanımları ve kapsamları. DEÜ Edebiyat Fakültesi Dergisi, 6(2), 527-552.

Ercan, G S. ve Dizdarc1, E. (2016). Medyada yarg1: Gazete köşe yazıları örneği. Uluslararası Hakemli İletişim ve Edebiyat Araştırmaları Dergisi, (12), 98119. Press.

Fairclough, N. (1992). Discourse and social change. Cambridge: Polity

Fairclough, N. (1995). Media discourse. London: Edward Arnold.

Fairclough, N. (2001). Language and power (2. bask1). London: Longman.

Fairclough, N. (2010). Critical discourse analysis: The critical study of language. London: Routledge.

Fairclough, N. ve Wodak, R. (1997). Critical discourse analysis. T. A. van Dijk (Haz.), Discourse as Social Interaction içinde (ss. 258-84). London: Sage.

Harvey, D. (1996). Justice, nature and the geography of difference. Oxford: Blackwell.

Oktar, L. (2001). "The ideological organization of representational processes in the presentation of Us and Them", Discourse and Society, 12, 313346.

Oktar, L. (2002). Gazete söyleminde ideolojik yapılar. S. Yağcıŏlu (Haz.), 1990 Sonrası Laik-Antilaik Çatışmasında Farklı Söylemler: Disiplinlerarası Bir Yaklaşım içinde (ss. 37-52). İzmir: Dokuz Eylül Yayınları.

Reisigl, M. (2017). The discourse-historical approach. J. Flowerdew ve J. E. Richardson (Haz.), The Routledge Handbook of Critical Discourse Studies içinde (ss. 44-59). London: Taylor \& Francis.

Reisigl, M. ve Wodak, R. (2001). Discourse and discrimination: Rhetorics of racism and antisemitism. London: Routledge. 
Reisigl, M. ve Wodak. R. (2008). The discourse-historical approach. R. Wodak ve M. Meyer, (Haz.), Methods of Critical Discourse Analysis içinde (ss. 87-121). London: Sage.

Richardson, J. (2007). Analyzing newspapers: An approach from critical discourse analysis. Houndmills: Palgrave.

Şimşek, H. ve Yıldırım, A. (2016). Sosyal bilimlerde nitel araştırma yöntemleri. Ankara: Seçkin Yayıncılık.

Wahl-Jorgensen, K. (2004). Playground of the pundits or voice of the people? Comparing British and Danish opinion pages. Journalism Studies, 5(1), 59-70.

Wodak, R. (2001). The Discourse-Historical Approach. R. Wodak ve M. Meyer (Haz.), Methods of Critical Discourse Analysis içinde (ss. 63-94). London: Sage.

Wodak, R. (2009). the discourse of politics in action: Politics as usual. Hampshire: Palgrave Macmillan.

Wodak, R. (2014). Critical discourse analysis. C. Leung ve B. V. Street (Haz.), The Routledge Companion to English Studies, içinde (ss. 302-316). New York:

Routledge.

Wodak, R. (2015). Critical discourse analysis, discourse-historical approach. K. Tracy, C. Ilie, T. Sandel (Haz.), The International Encyclopedia of Language and Social Interaction içinde (ss. 275-288). New York: John Wiley ve Sons.

Wodak, R. ve Meyer, M. (2001). Methods of critical discourse studies. London: Sage.

Wodak, R. ve Meyer, M. (2009). Critical Discourse Analysis: History, agenda, theory and methodology. Methods of Critical Discourse Analysis içinde (ss. 1-33). London: Sage.

van Dijk, T._A., (1998). Opinions and ideologies in the press. A. Bell ve P. Garrett (Haz.), Approaches to Media Discourse içinde (ss. 21-62). Oxford: Blacwell.

van Dijk, T. A. (2009). News, discourse, and ideology. K. Wahl-Jorgensen ve T. Hanitzsch (Haz.), The handbook of journalism studies içinde (ss. 211-224). Routledge.

Yağcığlu, S. (2002). Eleştirel Söylem Çözümlemesi: Disiplinlerarası bir yaklaşım. S. Yağcıŏglu (Haz.), 1990 Sonrası Laik-Antilaik Çatışmasında Farklı Söylemler: Disiplinler Arası Bir Yaklaşım içinde (ss. 3-34). İzmir: Dokuz Eylül Yayınları. 
Yağcioğlu, S. ve A. Cem-Değer (2001). Logos or mytos: (de)legitimation strategies in confrontational discourses of sociocultural ethos. Discourse and Society, 12(6), 817-852. London: Sage. 